\title{
An Empirical Study on the Status Quo of Foreign Language Volunteers in Zhoushan Archipelago New Area
}

\author{
SUN Lihang*, MAO Jiadai \\ No.1 South Haida Road Dinghai, Zhejiang Ocean University, Hangzhou, China
}

*Corresponding Author: SUN Lihang, No.1 South Haida Road Dinghai, Zhejiang Ocean University, Hangzhou, China

\begin{abstract}
Since 2016, the Zhoushan Archipelago New Area has actively responded to the development route of "the Belt and Road" which is proposed by President Xi Jinping, and the degree of internationalization keeps improving. Zhoushan has attracted more and more international activities and events held. At the same time, there is a serious shortage of foreign language volunteers who can serve International activities. Based on the demand for foreign language volunteers and some existing problems, we investigated some volunteers who are the member of Zhoushan international volunteer service base and analyzed the volunteers' service and English level in some international activities and events through the form of interviews and questionnaire. The aim is to provide a model for training and developing international volunteers in Zhoushan.
\end{abstract}

Keywords: English Volunteers; Volunteer Service; Improvement Measures; International Activities

\section{RESEARCH BACKGROUND}

Zhoushan has a unique geographical position, which is the gateway and channel for the opening of Yangtze River Basin and the Yangtze River Delta (WengWenge, 2003). Since the implementation of "the Belt and Road" in 2015, Zhoushan has accelerated the pace of international integration. (Li Tao, 2015). The pleasant climate and favorable geographical environment have attracted the attention of many people who are the organizers of the international events and conference. More and more international events will be held in Zhoushan. For example, in May 2016, the Zhejiang Zhoushan ArchipelagoNew Area Women's international road cycling competition was held in Shengsi county. There are 15 international squads, including the world's top 20 team a total of 6 , reflects the international popularity and importance of the competition. In September 2016, the international island tourism conference was held in the Zhoushan Archipelago New Area, which aims to create a platform for international island tourism dialogue, exchange and cooperation. There are about 100 foreign guests, with 40 overseas delegations from 26 countries and organizations. In November 2016, the marathon of Zhoushan Archipelago was opened in Putuo Poly Theater. There were thousands of athletes from 17 countries and regions in Australia, Germany, Russia, France, South Korea, the United States, the United Kingdom, Hong Kong and Taiwan. With the increase of the number of Zhoushan international competitions and foreign players, the demand for foreign language volunteers in Zhoushan Archipelago is increasing. (Lin Lihua, 2010), the demand for the ability of foreign language volunteers is getting higher and higher. In order to better provide volunteer service to international competition, on April 6, 2017 China (Zhejiang) free trade area of Zhoushan international volunteer service base established in Zhejiang ocean university, relying on universities in Zhoushan. At the base, the university student volunteers are setting up the service team. The base provides voluntary services for Boeing and other foreign companies in Zhoushan, as well as international events and activities in Zhoushan. The study has conducted a preliminary investigation on the status of volunteers in Zhoushan. According to the survey, the English level of the volunteer needs to be strengthened, mainly reflected in: 1. English communication barriers between volunteers and participants, namely, the volunteers have some difficulties in the expression of long difficult sentences in English. When the volunteers talk with the non-english speakers region people, they have difficulties in understanding of English pronunciation; 2. The volunteers have insufficient understanding of various activities and competitions, and are not well prepared in the translation of 
some professional terms and nouns. Therefore, how to improve the volunteers' English level is an urgent problem to be solved.

\section{EMPIRICAL RESEARCH}

\subsection{Object of Study}

The questionnaire interviewees are mainly from the 2017Zhejiang ZhoushanArchipelago New Area Women's international road cycling race volunteers and Chinese Zhoushan international sand sculpture festival volunteers. These two international competitions were held in 2017. They are large and professional, which can effectively respond to the problems existing in the volunteers, thus providing cases and materials for this study.The total number of respondents was 45, female volunteers accounted for $86.67 \%$, and male volunteers accounted for $13.33 \%$. Among them, $46.67 \%$ of the students majored in English, 33.33\% of the sophomores, and $20 \%$ in the third year.

The Ratio of Male and Female Volunteers

\begin{tabular}{|l|l|l|}
\hline \multicolumn{1}{|c|}{ Options } & \multicolumn{1}{|c|}{ Number } & \multicolumn{1}{c|}{ Proportion } \\
\hline Male & 6 & $13.33 \%$ \\
\hline Female & 39 & $86.67 \%$ \\
\hline
\end{tabular}

The Proportion of Volunteers in Grade

\begin{tabular}{|l|l|l|}
\hline \multicolumn{1}{|c|}{ Options } & \multicolumn{1}{c|}{ Number } & \multicolumn{1}{c|}{ Proportion } \\
\hline Freshman & 21 & $46.67 \%$ \\
\hline Sophomore & 15 & $33.33 \%$ \\
\hline Junior & 9 & $20 \%$ \\
\hline Senior & 0 & 0 \\
\hline
\end{tabular}

\subsection{Investigative Tools}

The main methods used in this study are questionnaire survey and direct interview. A total of 48 questionnaires were distributed and 45 valid questionnaires were recovered. The interview questions mainly include: 1. Volunteer service experience; 2. Volunteer service training; 3. The difficulties encountered by volunteers during the volunteer service and some solutions.

\section{Data Presentation}

\subsection{Analysis of the Results of Questionnaire Survey}

To participate in international competition volunteer service activities, we must have good English basis and volunteer service experience. The preliminary investigation has shown that most of the volunteers are the college students majoring in English, with some real English ability. But in listening, speaking, reading and writing translation of five aspects, they still have some problems.

First of all, this study investigates the volunteers' preparation, participation and training of voluntary service activities.

\subsubsection{The Problems of Voluntary Service}

\begin{tabular}{|l|l|l|}
\hline \multicolumn{1}{|c|}{ Options } & \multicolumn{1}{|c|}{ Number } & \multicolumn{1}{c|}{ Proportion } \\
\hline Poor communication with foreign friends, difficulty in oral communication. & 27 & $60 \%$ \\
\hline Some proper nouns cannot be translated in time & 36 & $80 \%$ \\
\hline Not familiar with the international competition process and make mistakes. & 15 & $33.33 \%$ \\
\hline
\end{tabular}

The main problems of volunteer service in volunteer service are analyzed in this study. $60 \%$ of the volunteers indicated that they were not able to communicate with foreign friends in volunteer service and had difficulty in oral communication, while $80 \%$ of the volunteers indicated that some proper nouns could not be translated in time. $33.33 \%$ of the volunteers had made mistakes because they were not familiar with international competitions or international conferences.

\subsubsection{Survey of Volunteer Service Experience}

The Number of Volunteers Participating in Voluntary Service

\begin{tabular}{|c|c|c|}
\hline \multicolumn{1}{|c|}{ Options } & \multicolumn{1}{c|}{ Number } & \multicolumn{1}{c|}{ Proportion } \\
\hline Once & 24 & $53.33 \%$ \\
\hline
\end{tabular}


An Empirical Study on the Status Quo of Foreign Language Volunteers in Zhoushan Archipelago New Area

\begin{tabular}{|l|l|l|}
\hline Twice & 15 & $33.33 \%$ \\
\hline Three times & 6 & $13.33 \%$ \\
\hline More than three times & 0 & 0 \\
\hline
\end{tabular}

Figures show that $53.33 \%$ of the volunteers participated involunteer service only once, $33.33 \%$ of the volunteers participated in the volunteer service twice, $13.33 \%$ of the volunteers participated in three volunteer service activities, and the number of volunteers who participated in more than 3 times was 0 . In general, volunteer experience in volunteer service is relatively short.

\subsubsection{A Survey of Volunteers' English Training}

Volunteers' Participation in the Training of Voluntary Service

\begin{tabular}{|l|l|l|}
\hline \multicolumn{1}{|c|}{ Options } & \multicolumn{1}{c|}{ Number } & \multicolumn{1}{c|}{ Proportion } \\
\hline Yes & 30 & $66.67 \%$ \\
\hline No & 15 & 33.335 \\
\hline
\end{tabular}

This study makes a statistical analysis of the English training of volunteers. The results showed that $66.67 \%$ of volunteershad received volunteer training at ordinary times, but such training was not strict and targeted, and there is a large gap between volunteers andinternational competitions or international conferences in demand. $33.33 \%$ of the volunteers said they did not have access to professional volunteer training activities in their daily life and they lack the opportunity to use English.

\section{Data Analysis}

According to the results of the questionnaire, this study makes the following analysis of the problems existing in voluntary service.

\subsection{Analysis of Problems Encountered in Voluntary Service}

These problems can be roughly divided into three aspects, such as oral ability, vocabulary, experience of voluntary service and so on. According to the survey, $61.54 \%$ volunteers indicated that they had not been able to communicate well with foreign friends in international activities and competitions. The difficulty in oralcommunication is a great difficulty encountered in the process of volunteering.Some foreign friends to participate in international competition and international session are not from english-speaking areas,their English pronunciation is not very standard (Li Chengxi, 2015), so volunteers often fail to learn the true meaning of foreign participants and guests, and sometimes have difficulty in understanding them. For volunteers, for a long time, they often neglect their oral English level in learning English, and seldom observe oral English in the learning process. They don't pay much attention to the cultivation of oral ability (Liu Yi etc. 2015). Secondly, in some large international competitions, the volunteers lack confidence (wang Yufeng, 2010) and volunteer service experience, and the oral English expression is even less proficient.At the same time, $76.92 \%$ of the volunteers were unable to explain proper nouns in a timely manner.International events or international conferences are professional, many technical terms are used during events or events, but these English words are less used in daily life.And most of the volunteers participate in volunteer service through the information provided by the school and the class. The time interval from becoming a formal volunteer to volunteering is very short.Volunteers have a limited understanding of events or meetings, and the professional terms and other vocabulary that emerged during the process have added obstacles to the successful completion of volunteering. In this case, volunteers often have problems in volunteering.In addition, 33.33\% of the volunteers made mistakes because they were unfamiliar with the process of international events or international conferences. The volunteers in this study were about 20 or 21 years old, most of them were freshmen and sophomores. The years of volunteer service are short and lack of experience, and most of the volunteers are from English major, with a wide range of knowledge and a single advantage. International events or international conferences are wide-ranging and professional which having high requirements for the comprehensive quality of volunteers. And from the volunteers to participate in the activities to the formal volunteer service time is compact, the understanding of international events or meetings is far from enough.

\subsection{Volunteer Service Experience Analysis}

The data showed that volunteers were lack of service experience. The main cause of the problem lies in the role of the volunteers themselves.Most of the volunteers are freshmen and sophomores 
majoring in English. In interviews, they said they would still focus on their studies. Volunteering was just a way to enrich their life and improve their foreign language level.At present, the international volunteer service activities which volunteer participated inmainly comes from some large international competitions or international conferences enrolled by school organizations, such as the Zhejiang Zhoushan Archipelago New Area Women's international road cycling race, Zhoushan Archipelago New Area international marathon race and so on.But there are still many small international competitions or international conferences that require foreign language volunteers. There are not many volunteers participating in small international activities.This study believes that this is closely related to the purpose of volunteers' participation in voluntary service activities. Their subjective initiative isn't strong enough. Volunteers don't know enough about the needs of voluntary service in all kinds of international activities timely and lack the enthusiasm of volunteer service, which leads to insufficient experience of volunteer service.Secondly, during the interview, this study also learned that liquidity is relatively large becausethe volunteers come from various colleges and universities, and most of them have plenty of spare time as freshman and sophomore. Because of the problems of employment and postgraduate entrance examination, few students can insist on volunteeringin the junior and senior years. The volunteer service life of volunteers is generally one to two years or even shorter. So it seems that there are not many experienced volunteers, and the volunteer service life is very short.In a word, the inadequacy of voluntary service and the low professional quality of the volunteers is a real problem

\subsection{Volunteer Service Training Analysis}

From the results of the survey, the volunteer service lacks the basic and perfect training system of volunteers. First of all, most of the volunteers come from the colleges and universities in Zhoushan islands. Although they have certain level of English skill, volunteers still have troubles in the communication with foreign friends, especially in the process of oral communication. And universities often lack the system especially for the professional training of volunteers in spoken language. Volunteers are not fully understanding of international events or international conferences, and there will be some problems in volunteering. Second, the international competitions or international conferences is highly specialized, and it is necessary for volunteers to know the background knowledge and relevant content of international events or conferences. But during the interview, we learned that the organizers would only conduct a simple volunteer training and explain the simple event or conference processafter recruiting volunteers. The organizers did not provide sufficient materials and background materials for volunteers to learn, so volunteers will have some trouble in the process of voluntary service.

\section{CONCLUSION}

In view of the present situation of international competition volunteers in Zhoushan Archipelago New Area, this study proposes a solution to the problem.

- Optimizing the sponsor's training system for volunteers. After recruiting volunteers, the organizers will give certain training to the volunteers according to the actual situation. However, there are also a few organizers who only offer simple introduce about international events or meetings to volunteers, and do not provide targeted training to volunteers.Therefore, it is very essential to improve the post-training system of volunteers. The sponsors can invite some instructors with rich experience to train volunteers in the five aspects of listening, speaking, reading, writing and translating. Organizers can also add some contents which about characteristic of international competitions or international conferences, so that volunteers can better integrate into the role of volunteer service in training contents.

- Coalition of college and enterprise, setting up professional volunteer training service base(Niu Shihua, 2008). In the interview, the study found that most of the volunteers were college students in Zhoushan Archipelago, and universities were very supportive of students' volunteer activities.At the same time, some companies will supportinternational events and international conferences. In this context, it is a win-win strategy for schools and enterprises to establish a professional volunteer training service base. This can not only reduce the cost and energy of later training, but also improve the volunteer service level and prolong the volunteer service life.This one has practice, on April 6, 2017, China (Zhejiang) free trade area 
Zhoushan international volunteer service base established in Zhejiang ocean university, relying on universities in Zhoushan. The base is setting up by college students volunteers to provide volunteer service for the foreign companiesin Zhoushan such as Boeing, foreign exchange and international competitions and activities.

- Establishing effective assessment and reward mechanism (Zhang Jingjing etc., 2017). Most of the volunteers in the interview talked about the purpose of participating in volunteer service activities to enrich their college life experience and improve their oral English. At the same time, the volunteers also hope that these social practice experiences will be a plus for their future job placement and postgraduate entrance examination. Therefore, it is necessary to establish an effective assessment and incentive mechanism.

Giving special certificates and giving rewards to volunteers who have outstanding performance in vol unteer service is the motive force to inspire volunteers to provide high quality volunteer service.

\section{EPILOGUE}

Based on the needs of volunteers in Zhoushan and the problems existing in volunteers, this study adopts the field interview and questionnaire survey method, through investigating and analyzing the condition of international activities held in Zhoushan,the English level of the volunteers and foreigners evaluation of volunteers, to explore a feasible way to improve the level of volunteer English. This study in order to improve the Zhoushan international volunteer activities and competition, English level are proposed, for China (Zhejiang) free trade area Zhoushan international volunteer service base to provide better training mode. The study provides suggestions for improving the English level of volunteers in Zhoushan international activities and competitions and provides a better training model for the Zhoushan international voluntary service base in China (Zhejiang) free trade test area.

\section{REFERENCES}

[1] 林丽华.高校中外教师英语口语教学实证研究【J】.武汉工程大学学报，2010，32（8）：98～101.

[2] 牛实华，哈尔滨大冬会志愿者英语培训研究【J】.冰雪运动，2008，30（5）:51～55

[3] 张晶晶，常朝朝，2016唐山世园会志愿者英语服务能力提升策略研究【J】.工业技术与职业教育， 2014 (3) : 80 82.

[4] 李盛曦, 大学生国际活动志愿者对世界英语的态度及适应性研究【J】.广州城市职业学院学报, 20 $15, \quad 9$ (4) :91 100.

[5]张晶晶, 张立华, 田红磊，董艳娇，唐山市国际性活动志愿者英语服务能力研究【J】.工业技术与 职业教育，2017，15（1）:82〜85.

[6] 王玉凤，高职英语阅读策略实证研究【J】.山东英才学院学报，2010，6（3）:34～3

[7]刘怡, 杨晋, 高凌萱, 论青奥背景下大学生英语实践能力的培养【J】.科教文汇旬刊，2015（19） : $162 \sim 164$.

[8] 王一婷, 刘晓丹，国际活动外语志愿者的现状及培养探究【J】. 管理观察，2016（31）：58６1.

Citation: SUN Lihang, MAO Jiadai. "An Empirical Study on the Status Quo of Foreign Language Volunteers in Zhoushan Archipelago New Area" International Journal of Humanities Social Sciences and Education (IJHSSE), vol 6, no. 1, 2019, pp. 81-85. doi: http://dx.doi.org/10.20431/2349-0381.0601010.

Copyright: () 2019 Authors. This is an open-access article distributed under the terms of the Creative Commons Attribution License, which permits unrestricted use, distribution, and reproduction in any medium, provided the original author and source are credited. 